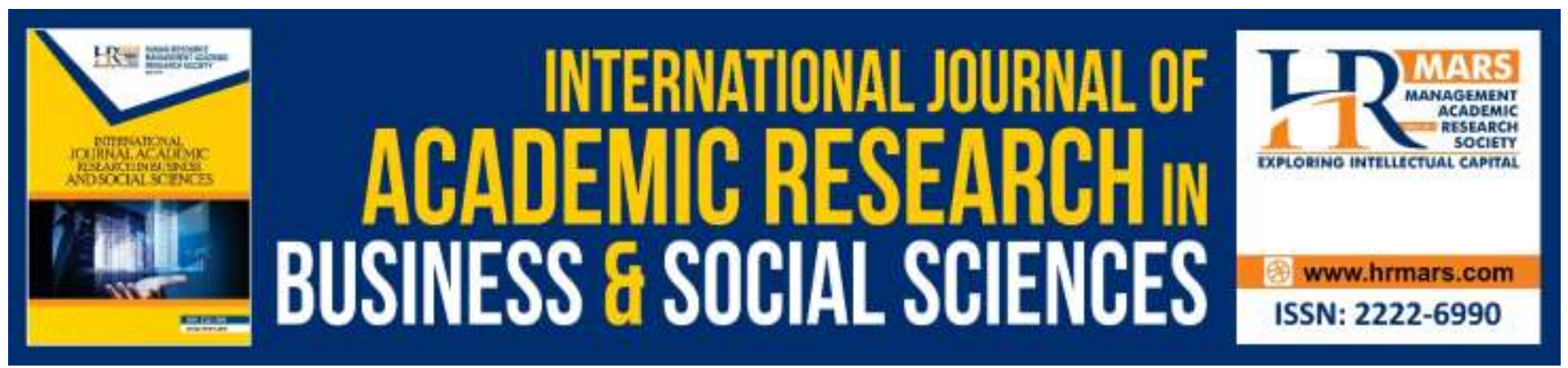

\title{
E-commerce Advertising: Does the Traditional Advertising Elements Still Relevant?
}

Tan Owee Kowang, Rosy Awing Jacob, Lim Kim Yew, Ong Choon Hee, Goh Chin Fei, Choi Sang Long

To Link this Article: http://dx.doi.org/10.6007/IJARBSS/v9-i7/6103 DOI: $10.6007 /$ IJARBSS/v9-i7/6103

Received: 28 May 2019, Revised: 11 June 2019, Accepted: 01 July 2019

Published Online: 23 July 2019

In-Text Citation: (Kowang et al., 2019)

To Cite this Article: Kowang, T. O., Jacob, R. A., Yew, L. K., Hee, O. C., Fei, G. C., \& Long, C. S. (2019). E-commerce Advertising: Does the Traditional Advertising Elements Still Relevant? International Journal of Academic Research in Business and Social Sciences, 9(7), 191-201.

Copyright: (C) 2019 The Author(s)

Published by Human Resource Management Academic Research Society (www.hrmars.com)

This article is published under the Creative Commons Attribution (CC BY 4.0) license. Anyone may reproduce, distribute, translate and create derivative works of this article (for both commercial and non-commercial purposes), subject to full attribution to the original publication and authors. The full terms of this license may be seen

at: http://creativecommons.org/licences/by/4.0/legalcode

Vol. 9, No. 7, 2019, Pg. 191 - 201

http://hrmars.com/index.php/pages/detail/IJARBSS

JOURNAL HOMEPAGE

Full Terms \& Conditions of access and use can be found at http://hrmars.com/index.php/pages/detail/publication-ethics 


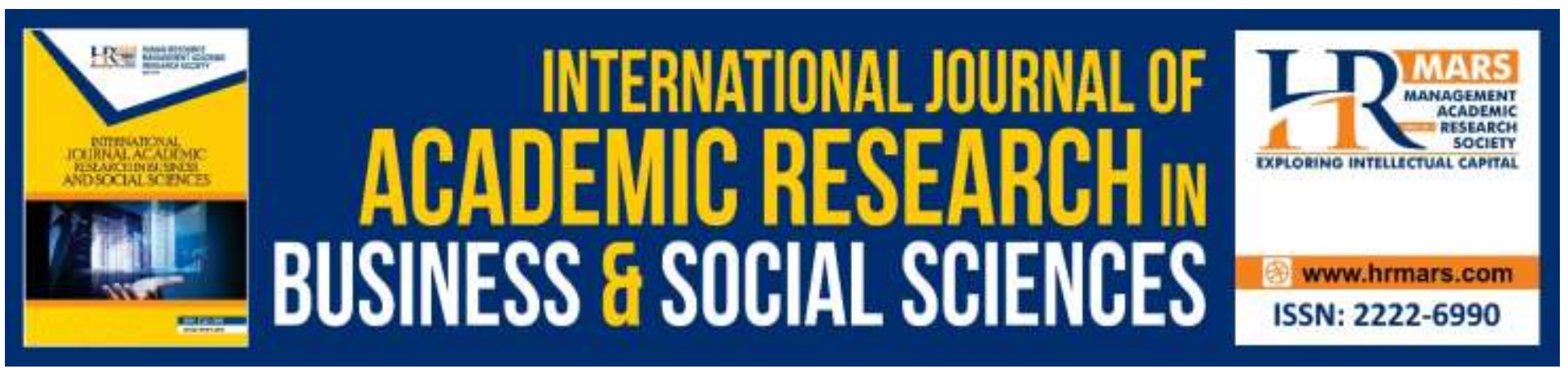

\section{E-commerce Advertising: Does the Traditional Advertising Elements Still Relevant?}

\section{${ }^{1}$ Tan Owee Kowang, ${ }^{1}$ Rosy Awing Jacob, ${ }^{2}$ Lim Kim Yew, ${ }^{1}$ Ong Choon Hee, ${ }^{1}$ Goh Chin Fei, ${ }^{3}$ Choi Sang Long}

${ }^{1}$ Azman Hashim International Business School, Universiti Teknologi Malaysia, Johor, Malaysia, ${ }^{2}$ INTI International University, Nilai, Malaysia, ${ }^{3}$ Raffles University, Iskandar, Malaysia

Email:oktan@utm.my

\section{Abstract}

The substantial growth of beauty products' demand from both domestic and export markets has made beauty product become one of the important sectors of economy in Malaysia. On top of continuously introducing new beauty product to the marketplace, advertising of new beauty products is another important mechanize to ensure new product success in the competitive business environment. Recently, e-commerce of beauty product is emerging rapidly in the local marketplace. E-commerce serves as the platform for both online advertising (or namely e-commerce advertising) and online purchase. In addition, the success of e-commerce (which commonly measure in term of customers purchase intention) is very much dependent on the elements of e-commerce advertising. As such the aim for this study is to assess does the traditional advertising elements still stay relevant to e-commerce advertising of beauty product. In conjunction with this, the study explores the relationship between e-commerce advertising elements (which are medium credibility, entertaining celebrities association, quality features of product, advertising frequency, brand image and informativeness) and consumers' online purchase intention of beauty products in Malaysia. The study is quantitative based, data was collected from 260 females between age of 18 to 25 years. Preliminary data analysis was done to assess the normality and reliability of the data, followed by analysis of correlation via Pearson correlation test. Analysis result from Person correlation suggested within the scope of the population under study, three traditional advertising elements still stay relevant to e-commerce advertising of beauty product, which are brand image, quality features of the product and informativeness of advertising.

Keywords: E-commerce, Purchase Intention, Medium Credibility, Quality Features of Product, Advertising Frequency, Brand Image, Entertaining Celebrities Association. 


\section{Beauty Product Market in Malaysia}

The "Personal care and cosmetics" market or namely the "Beauty products" market in the Asia region has shown a significant growth for the past few years. According to the Asia Personal Care and Cosmetics (i.e. beauty products) Market Guide, Asia countries offered over three million potential consumers, or $32 \%$ of the global beauty products marketplace, and is expected to grow by $6.7 \%$ over the next five years. In Malaysia, the total trade volume for beauty products was about USD2.24 billion in year 2016, and is expected to increase by 9 to 11\% yearly. Meantime, report released by the Malaysian External Trade Development Corporation (MATRADE) revealed that Malaysia's domestic manufacturers of beauty products exported about USD 270 million beauty products yearly. In addition, according to MATRADE, despite of the lower GDP growth in Malaysia, the beauty products industry in Malaysia is expected to secure a continuous growth of $5 \%$ yearly. Hence, the substantial growth of domestic demand on beauty products as well as the continuous growth of export market has made beauty products become one of the important sectors of economy in Malaysia.

\section{E-commerce of Beauty Product}

To fulfil the demand and growth of domestic market, beauty products industry in Malaysia should not only focus on introducing new beauty products to the marketplace continuously, but also need to ensure that the new product is made known to the targeted consumer group, creating consumers intention to purchase, and ultimate purchase (Schimmoeller, 2010). Hence, marketing and advertising of new beauty products turn to be one of the important mechanize to ensure new beauty product success.

Traditionally, beauty products in Malaysia are introduced and sold to consumers via conventional marketing and advertising channels such as through spas, salons, retail stores, or via multi-level marketing and direct selling channel (APCCMG, 2016). Recently, e-commerce of beauty products such as "Modbox", "Luxola", "HiShop" and "Shins" are emerging rapidly in the local marketplace. About $2 \%$ of the sales in Malaysia is done via e-commerce and it is predicted to grow to double digit by 2020. The prediction is supported by the fact that the digital population in Malaysia is more than 20 million people. In addition, the e-commerce platform in in Malaysia is relatively more established as compared with the other countries in ASEAN (except Singapore).

E-commerce platform is not only serving as the platform for on-line business transaction, it is also acts as the landscape for on-line advertising or namely e-commerce advertising (Chu et. al., 2012). As such, the success of e-commerce (which commonly measure in term of customers purchase intention) is very much dependent on the approach and elements of e-commerce advertising (Xiaoli and Pussadee, 2012). Hence, this study aims to assess does the traditional advertising elements still stay relevant to e-commerce advertising of beauty product. In conjunction with this, the study explores the relationship between e-commerce advertising elements and consumers purchase intention of beauty product, with the focus among young female in Malaysia within age range of 18 to 25 years. As such, the main research objective $(\mathrm{RO})$ for this study is: 
INTERNATIONAL JOURNAL OF ACADEMIC RESEARCH IN BUSINESS AND SOCIAL SCIENCES Vol. 9, No. 7, July, 2019, E-ISSN: 2222-6990 @ 2019 HRMARS

RO: To explore the relationship between e-commerce advertising elements and consumers' online purchase intention for beauty products in Malaysia.

\section{Important Elements for E-commerce Advertising}

E-commerce advertising forms a crucial part of the e-commerce landscape (Tavor, 2011). The main objective of e-commerce advertising is to influence the consumers' purchase intention via the "purchase funnel" concept, which starts with creating product awareness, promoting consideration to purchase and eventually purchase online (Ansari and Joloudar, 2011). Hence, an effective ecommerce advertising transformed customer awareness towards purchase. Studies done by prior scholars revealed that advertising is the important success factor for e-commerce. Literature review that conducted on advertising and e-commerce advertising revealed that there are 6 common elements that proposed by prior researchers as important elements for advertising and ecommerce advertising success, which are summarized in Table 1.

Table 1. Important Elements for e-Commerce Advertising

\begin{tabular}{|l|l|}
\hline $\begin{array}{l}\text { Important elements for e- } \\
\text { commerce advertising }\end{array}$ & Previous Research \\
\hline Medium Credibility & $\begin{array}{l}\text { Ohanian (1990); Adler \& Rodman (2000); Gerard, } \\
\text { Derek and Poon (2009) }\end{array}$ \\
\hline Quality Features of Product & $\begin{array}{l}\text { (Dawar and Parker, 1994); Ansari and Joloudar } \\
(2011) .\end{array}$ \\
\hline Advertising Frequency & $\begin{array}{l}\text { Krugman (1972); Zabadi and Elsayed (2012); Chu et. } \\
\text { al. (2012) }\end{array}$ \\
\hline Brand Image & $\begin{array}{l}\text { Dobni and Zinkhan (1990); Tavor (2011), Chu et. al. } \\
(2012)\end{array}$ \\
\hline $\begin{array}{l}\text { Entertaining Celebrities } \\
\text { Association }\end{array}$ & $\begin{array}{l}\text { Kahle and Homer (1985); Nunn and Biressi (2010); } \\
\text { Ahmed (2014) }\end{array}$ \\
\hline Informativeness & $\begin{array}{l}\text { Nelson (1974); Tavor (2011), Xiaoli and Pussadee } \\
(2012)\end{array}$ \\
\hline
\end{tabular}

\section{Medium Credibility}

Medium credibility can be defined as customers' acknowledgement toward the information conveyed by advertising medium. Credibility is also viewed as the impression of the audiences toward the advertisement regardless of it is good or bad (Adler \& Rodman, 2000). From advertiser perspective, credibility refers to how credible the company and the advertising agency in transferring the message to the consumers (Gold smith, 2000). Studies by Ohanian (1990) and Adler \& Rodman (2000) suggested that medium credibility has significant impact towards consumers' purchase intention. Credibility of advertising is not only depends on the product that advertised, it is also affected by in what way it is advertised and how the message is delivered to the audiences or potential customers (Aaker and Brown, 1972; Gold smith, 2000). 


\section{Quality Feature of Product}

Quality has been defined as conformity of the usage, or the degree of how a product fulfils the expectation of consumers (Beverly et al., 2002). Hence, consumers might refer quality as brand name, price, reputation of the retailer and the appearance of the product, which is dependents on consumes' individual expectation (Dawar and Parker, 1994). Therefore, the process of defining product's quality should take into account to understand the impression and belief of the consumer in order to offer a product that fulfil the consumers' expectation of quality (Dawar and Parker, 1994; Ansari and Joloudar, 2011)

\section{Advertising Frequency}

Advertisements convey a functional and emotional message with the ultimate aim to give positive impact toward consumer purchase intention (Zabadi and Elsayed, 2012). Studies done by prior researchers (Krugman, 1972; Zabadi and Elsayed, 2012) suggested that repetition of advertisements enhance consumers purchase intention. The first few rounds of advertising aims to create consumers' awareness toward the existent of the product, while the subsequent series of advertising aims to initiate an intention of experiencing or trying the product which will subsequently enhance consumer's purchase intention Chu et. al. (2012). These incremental impacts made advertising frequency become one of the important element toward consumers' purchase intention.

\section{Brand Image}

Kotler (2000) defined brand image as the merger of a nominal, name, layout, and emblem of a particular product. The main objective of creating a brand image is for the consumers to differentiate between the products from the rest that available in the marketplace. Brand image involves consumer's understanding and perception towards the brand's variety, including the internal and external features of the product. It is also represents the consumer's assessment toward brandrelated information and exclusive comparison that consumers made with similar brands or products. Hence, brand image is another important e-advertising element that enhance consumer purchase intention (Dobni and Zinkhan, 1990; Tavor, 2011, Chu et. al., 2012).

\section{Entertaining Celebrities Association}

From advertising perspective, celebrities refer to individuals who are famous or well known in particularly among the potential consumers (O'Guinn, 1991). Study by prior researchers (Kahle and Homer, 1985; Nunn and Biressi, 2010; Ahmed, 2014) revealed that the popularity and appearance of the celebrity have high influence toward the brand image as well as the effectiveness of the advertisement. As the result, consumers have tendency to attach with the product (Nunn and Biressi, 2010). Study done by Choi and Rifon (2012) also suggested that the behavior of the consumer purchase decisions is closely related to the celebrities image that be depicted in the advertisement.

\section{Informativeness}

Informativeness is regarded as the effectiveness of advertisement in conveying the products information to the potential consumers, so that the consumers can make their decision on purchase the product with higher gratification (Ducoffe, 1996). Indeed, product information is the fundamental 
elements that need to be channelled to the consumers, failing of doing this could undermine objective of advertisement (Nelson, 1974; Tavor, 2011, Xiaoli and Pussadee (2012)). In addition, study from Chen (1999) also revealed that the messages and information delivered in an advertisement have positive relationship with the consumer impression and belief.

\section{Research Framework}

The research framework for this study is developed based on the concept that effective e-commerce advertising will lead to online purchase intention by consumers upon an evaluation based on their attitudes and belief (Ahmed, 2014). Hence, the research framework shown in Figure 1 made up of the six important e-commerce advertising elements identified in the literature review as independent variables and online purchase intention of beauty product as dependent variable.

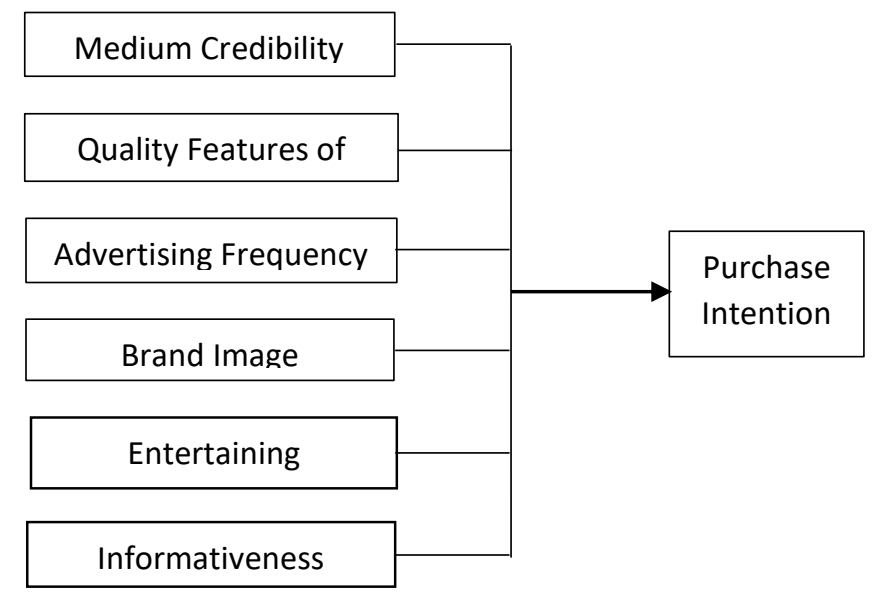

Figure 1. Research Framework

Purchase intention, the dependent variable of the research framework is referring to a person's mindful way of making their attempts to make purchasing on a particular product (Spears \& Singh, 2004). Dodds et al. (1991) defined purchase intention as the tendency that a purchasing decision will be made. Whereas, Yoo et.at. (2000) viewed purchase intention as customers' desire in making purchase decisions based on the perception of information received via advertising. In conjunction with this, six hypotheses are developed in line with the research framework.

H1: Medium credibility (MC) is positively related to purchase intention (PI).

H2: Quality features of product (QFP) is positively related to purchase intention (PI).

H3: Advertising frequency (AF) is positively related to purchase intention (PI).

H4: Brand Image (BI) is positively related to purchase intention (PI).

H5: Entertaining celebrities association (ECA) is positively related to purchase intention (PI).

H6: Informativeness (IN) is positively related to purchase intention (PI).

\section{Population and Sampling}

According to Asia Personal Care and Cosmetics Market Guide 2016, the younger generation females in the age group of 18 to 25 range made up the major market segment for beauty product. Hence, the population for this study was young female between ages of 18 to 25 from southern part of 
Malaysia. Convenience sampling technique was used as sampling method for this study. The calculation of the sample size was based on the '10-times rule' proposed by Hair et.al. (2013). Based on the "10-times rule" method, sample size is estimated by 10 times the maximum number of arrows pointing at any latent variable in the research model or framework. Since there are six independent variables pointing dependent variables, the proposed sample size is 60 (6 X 10). In addition, by taking into the consideration that the respond rate of similar research conducted in Malaysia is approximately $60 \%$, hence a targeted sample size is set as 100 (i.e. 60 divided by $60 \%$ ).

\section{Data Collection Method}

The study was quantitative based, Questionnaire were distributed to targeted respondents at few shopping malls within southern part of Malaysia. The questionnaire consist of 28 questions which are divided into two parts. First part was to collect the respondents' demographic information, while the second part of the questionnaire was to assess respondents' agreement level on the six important e-advertising elements as well as purchase intention for beauty product. The second part of questionnaire is adapted from the previous studies of e-commerce and advertising (Gerard, Derek and Poon,2009; Ansari and Joloudar, 2011; Chu et. al., 2012; Ahmed, 2014). The assessment was done via 5-points scales from " 1 " representing "Total disagreed" to " 5 " indicating "Totally agreed".

A total of 400 questionnaires were distributed with 263 responded. However, 3 unusable questionnaires were screened out due to missing value. As the result, 260 usable questionnaires were collected, which is above the targeted sampling size of 100 , with the respond rate of $65 \%$.

\section{Normality Test and Reliability Test}

A preliminary analysis was done on data collected from part 2 of questionnaire to assess the normality and reliability of data collected prior to further analysis. Normality of data was assessed via the Skewness and Kurtosis of data. Result of analysis shown that the value of Skewness and Kurtosis of all measurement items are within -2 and +2 , hence there is no issue in regard with data normality (Hair et al. 2010). Meantime, reliability of data was evaluated via Cronbach's Alpha test. The Cronbach's Alpha for all the e-advertising elements and purchase intention are above 0.70, this suggests that there is no issue on reliability for the data collected, hence the data can be proceed for further analysis.

\section{Pearson Correlation}

To address the research question for this study (i.e. To explore the relationship between e-commerce advertising elements and consumers' online purchase intention for beauty products in Malaysia), as well as to test the six research hypotheses, data collected from part 2 of questionnaires is further analysed via Pearson correlation test. The purpose of Pearson correlation test is to assess the relationship between the important elements of e-commerce advertising and online purchase intention of beauty product. The result of analysis is summarized in Table 2. 
INTERNATIONAL JOURNAL OF ACADEMIC RESEARCH IN BUSINESS AND SOCIAL SCIENCES Vol. 9, No. 7, July, 2019, E-ISSN: 2222-6990 @ 2019 HRMARS

Table 2. Result of Pearson Correlation Analysis

\begin{tabular}{|ll|r|r|r|r|r|r|r|}
\hline & \multicolumn{1}{c|}{ MC } & \multicolumn{1}{c|}{ AF } & \multicolumn{1}{c|}{ ECA } & \multicolumn{1}{c|}{ BI } & \multicolumn{1}{c|}{ IN } & \multicolumn{1}{c|}{ QFP } & PI \\
\hline PI & Pearson & -.038 & -.033 & .001 & $.425^{* *}$ & $.428^{* *}$ & $.309^{* *}$ & \\
& Correlation ( $\mathrm{r}$ ) & & & & & \\
& Sig. (2-tailed) & .547 & .595 & .987 & .000 & .000 & .000 & \\
$\mathrm{~N}$ & 260 & 260 & 260 & 260 & 260 & 260 & 260 \\
\hline
\end{tabular}

As refer to Table 2, the significant value (i.e. sig) for three of the e-commerce advertising elements, which are Brand image (BI), Informativeness (IN) and Quality features of product (QFP) are less than 0.05. This suggested that at confidence level of 95\%, the relationship between these three e-commerce advertising elements with online purchase intention of beauty product are significant, with person correlation coefficient of 0.309 to 0.425 (i.e. moderately correlated).

Whereas, the relationship between the other three e-commerce advertising elements, Medium credibility (MC), Advertising frequency (AF) and Entertaining celebrities association (ECA) with online purchase intention for beauty product were not significant at level of 0.05. Hence, based on the analysis result of Person correlation test, three of the hypotheses for this study are supported, and the other three are failed to support (refer to Table 3.).

Table 3. Result of Hypotheses Testing

\begin{tabular}{|c|c|c|}
\hline Hypotheses & Variables & Results \\
\hline $\mathrm{H} 1$ & Medium Credibility $\rightarrow$ Purchase Intention & Failed to support \\
\hline $\mathrm{H} 2$ & Quality Features of Product $\rightarrow$ Purchase Intention & Supported \\
\hline $\mathrm{H} 3$ & Advertising Frequency $\rightarrow$ Purchase Intention & Failed to support \\
\hline $\mathrm{H} 4$ & Brand Image $\rightarrow$ Purchase Intention & Supported \\
\hline $\mathrm{H} 5$ & Entertaining Celebrities Association $\rightarrow$ Purchase & Failed to support \\
\hline $\mathrm{H} 6$ & Information & Supported \\
\hline
\end{tabular}




\section{Discussion and Conclusion}

Finding from the study reveals that e-advertising element "Brand image" is positive and significantly correlated with online purchase intention of beauty product. The finding is in parallel with study done by Bian and Mautinho (2011) which suggested that brand image significantly influence consumers' purchase intention. Hence, from beauty product e-commerce advertising perspective, finding from this study suggested the higher the degree of consumers' trustfulness toward the product's brand, the higher the online purchase intention.

Analysis result from this study also reveals that e-advertising element "Informativeness" is positive and significantly correlated with online purchase intention of beauty product. This finding echoes study done by Huq et al. (2015) which concluded that consumers have tendency to purchase product that advertised with full detail of product and application information. Study by Eze et. al., (2012) also suggested that consumers in the $21^{\text {st }}$ century tend to search and compare products from the same category prior to make the decision of purchase. Hence, finding from this study reveals that the more positive information the consumer could gathered from e-commerce advertising, the more likely the consumer will place a purchase online.

Finding from this study also suggested that Quality features of product has a significant and positive relationship towards online purchase intention of beauty product. The finding supports Eze et. al., (2012) and Sidiqqui (2014) studies which both revealed that quality feature of product impose a significant influence toward consumer purchase intention. In addition, according to Alexander (2011), due to high competitiveness of beauty product market, quality feature of product nowadays become one of the most important criteria used by consumer to compare and select product to purchase. However, finding from this study also reveals that e-commerce advertising elements medium credibility, advertising frequency and entertaining celebrities association did not established a significant relationship with online purchase intention for beauty product. The relationship between entertaining celebrities and online purchase intention was found insignificant. The result opposes finding of prior researchers (Kahle and Homer, 1985; Nunn and Biressi, 2010; Ahmed, 2014). This finding suggested that within the context of young female in Malaysia, the behavior of online purchase decision is closely associated with the product brand and product quality while celebrities' image that depicted in the advertisement is less important.

Unlike the other conventional advertising medias such as printed (such as newspaper, poster) and non-printed (such as radio and television) advertising, the frequency of advertising, or the repetition of the e-commerce advertising is unlimited and beyond the control of the advertiser. Instead, the need and the number of repetition are purely dependent on the consumers. Consumer could replay or review the online advertising based on individual needs. Perhaps, this is the reason of the insignificant relationship between advertising frequency and online purchase intention. In addition, printed advertising medium are commonly agreed by prior studies (Moore and Rodgers, 2005. Zheng et. al., 2009; ) that it offers a stronger credibility, where online advertising is viewed as the least credible medium to advertise. Perhaps, this is reason that explained the insignificant relationship between medium credibility of e-commerce advertising and online purchase decision of beauty product. 
The implication of this finding is, within the scope of the population under study, three traditional advertising elements still stay relevant to e-commerce advertising of beauty product, which are brand image, quality features of the product and informativeness. Whereas, the other three traditional advertising elements, medium credibility, advertising frequency and entertaining celebrities are found irrelevant to e-commerce advertising of beauty.

\section{Acknowledgements}

Authors wish to acknowledge the Malaysian Ministry of Education and Universiti Teknologi Malaysia under the Research Grant (Vote No. 18H59) for sponsoring this publication.

\section{References}

Aaker, D. A. and Brown P. K. (1972), "Evaluating vehicle source effects", Journal of Advertising Research, 12 (4), 11-16.

Adler, R. B. and Rodman, G. (2000), "Understanding Human Communication", 7th ed., Ahmed Nabeel Sidiqui, (2014), "TV Ads Impact on Consumer Purchase Intention", International Conference on Marketing.

Ansari, M. E. and Joloudar, Y. E. (2011). An Investigation of TV Advertisement Effect on Customers". International Journal of Marketing Studies, 175-181.

Harcourt College Publishers, Ft Worth, TX

Beverly, K. K., Diane, M. S, and Richard, Y. W. (2002), “Information Quality Benchmarks: Product and Service Performance", Communications of the ACM, Vol. 45, No. 4.

Bian, X. and Moutinho, L. (2011), "The role of brand Chinese Americans", Journal of Consumer Marketing, image, product involvement and knowledge in 28(3): 169-177.

Chu, Chih-Chung, Chang, C. Lee., Wei-Chun, Lin and Yau-Nang, (2012), "The Effect of Advertisement Frequency on the Advertisement Attitude-The controlled Effects of Brand Image and Spokesperson's Credibility", Social and Behavioral Science, Vol 57 pp. 352-359.

Choi, S. M. and Rifon, N. J. (2012), "It is a match : The impact of congruence between celebrity image and consumer idea self on endorsement effectiveness", Psychology and Marketing, Vol. 29 No. 9, pp 639-650.

Dawar, N. and Parker, P. (1994), "Marketing universals: consumers' use of brand name, price, physical appearance, and retailer reputation as signals of product quality", Journal of Marketing, Vol. 58 No. 2, pp. 81-95.

Dobni, D., and Zinkhan, G. M. (1990), "In search of brand image: a foundation analysis", Advances in consumer research, 17(1), 110-119.

Dodds, W. B., Monroe, K. B. and Grewal, D. (1991), "Effects of prices, brand and store information on buyers' product evaluations", Journal of Marketing Research, Vol. 28, pp. 307-319.

Ducoffe, R. (1996), "Advertising value and advertising on the websites", Journal of

Advertising Research, 465, 21- 35.

Eze, U. C., Tan, C. B., and Yeo, A. L. Y. (2012), "Purchasing cosmetic products: A preliminary perspective of gen- $Y$ ", Contemporary management research, 8(1), 51-60.

Gerard Prendergast Po-yan Liu Derek T.Y. Poon, (2009),"A Hong Kong study of advertising credibility", Journal of Consumer Marketing, Vol. 26 Iss 5 pp. 320 - 329 
INTERNATIONAL JOURNAL OF ACADEMIC RESEARCH IN BUSINESS AND SOCIAL SCIENCES

Vol. 9, No. 7, July, 2019, E-ISSN: 2222-6990 ¿C 2019 HRMARS

Smith, G. R. (2000), "The impact of Corporate Credibility and celebrity on consumer reaction to advertisements and brands", Journal of Advertising, 29(3), 43 - 54.

Hair, J. F., Black, W. C., Babin, B. J., and Anderson, R. E. (2010). Multivariate Data Analysis (7th ed.). NJ: Prentice Hall.

Kahle, L. R and Homer, P. M. (1985), "Physical attractiveness of celebrity endorser: a social adaptation perspective", Journal of Consumer Research, 11 March, pp. 954-961.

Kotler, P. (2000), 'Marketing Management: Analysis, Planning, Implementation, and Control", $7^{\text {th }}$ (Ed.), New Jersey: Prentice Hall.

Krugman, Herbert E. (1972), "Why Three Exposures May Be Enough", Journal of Advertising Research, 12 (6), 11-14.

Moore, J. J., \& Rodgers, L. R. (2005). An Examination of Advertising Credibility and Skepticism in Five Different Media Using the Persuasion Knowledge Model, American Academy of Advertising Conference Proceedings, Januari 1, 10.

Nelson, P. (1974), "The Economic Value of Advertising, in Y. Brozen (ed.)", Advertising and Society, (pp. 43-65).

Nunn, H. and Biressi, A. (2010), "A trust betrayed: celebrity and the work of emotion", Celebrity Studies, Vol.1 No.1, pp.49-64.

Ohanian, R. (1990), "Construction and validation of a scale to measure celebrityendorsers' perceived expertise, trustworthiness, and attractiveness", Journal of Advertising, 19(3), 39-52.

Spears, N. and Singh, S. N. (2004), "Measuring Attitude toward the Brand and Purchase Intentions", Journal of Current Issues and Research in Advertising, 26(2), 53-60

Tavor. (2011). Online Advertising Development and Their Economic Effectiveness. Australian Journal of Business and Management Research. 1(6), 121-133.

Wang, X., Polsaram, P. (2012), and D.B.A, "Attitude toward the Advertising and Subjective Norm on Purchase Intention: A Case of Television Advertising of Beauty and Personal Care Product in Bangkok", Journal of Finance.

Yoo, W.-S., Lee, Y. and Park, J. (2010), "The role of interactivity in e-tailing: creating value and increasing satisfaction", Journal of Retailing \& Consumer Services, Vol.17 No.2, pp.89-96.

Zabadi, A., and Elsayed, E. (2012). Consumer attitude towards SMS advertising among Jordanian users. International Journal of Marketing Studies. 4(1), 77-94. 